10 For a full description of the copy Traubel mailed to Tennyson, see Brewer/Feinberg, 120.

11 I would like to thank the Department of English and the Faculty Development Committee, Marietta College, for funding which helped support the research and publication of this article.

The inspiration for this article is a signed and dated copy of Camden's Compliment which I purchased in the early 1960s at The Wolcott Shop in Skaneateles, New York. My stop there occurred while Ralph Schroeder and I were on one of our frequent gathering excursions to collect information and material about Vachel Lindsay. On the front pastedown endpaper of my copy is the identifying code "W 1022," probably an indication of the book's location in the Wolcott inventory; on the front free endpaper are the autograph and date: "Walt Whitman/Dec: 16 '89." Confirmation of the existence of this book is found in WWC, 6. Except for certain copies Traubel mailed, distribution of most local copies was in the hands of Attorney Thomas B. Harned and Judge Charles G. Garrison of Camden. Traubel's entry about Whitman for December 16, 1889 is both typical and telling: "Harned, he said, had just left the house. . . . He brought me down a dozen copies of your book. It seems that Judge Garrison is to take them, and wants my signature. Oh yes! I shall sign them-sign them for Tom and for the Judge, both, for their sakes." Later on December 21, Whitman noted: "We have a good friend in Judge Garrison. . . . I think he must have distributed as many as 30 copies of your book. . ." (WWC, 6:197, 205). Since the sixth volume of Traubel was not published until 1982, about twenty years after I purchased my copy of Camden's Compliment, there would not have been any public way for me to know until 1982 that my copy apparently was one of a dozen brothers. This raises many intriguing questions, two of which might be, to whom did Judge Garrison originally give or sell my copy, and by what route did it then make its way to the cozy Wolcott Shop in upstate New York? Perhaps a more answerable question might be, how many of my copy's eleven brothers have survived to this day and at what address(es)?

\title{
GERTRUD KOLMAR'S RESPONSE TO WALT WHITMAN
}

When Gertrud Kolmar, a.k.a. Chodziesner, was "disappeared" by the Nazis in February 1943, much of her poetry had already been sent out of Germany. Some had lines like those in "The Woman Poet" ("Die Dichterin"), which are reminiscent of such Whitman poems as "Whoever You Are Holding Me Now in Hand" and "So Long!":

Du hältst mich in den Händen ganz und gar.

... Der du dies liest, gib acht;

Denn sieh, du blätterst einen Menschen um.

Doch ist es dir aus Pappe nur gemacht,

Aus Druckpapier und Leim, so bleibt es stumm

Und trifft dich nicht mit seinem grossen Blick,

Der aus den schwarzen Zeichen suchend schaut . . . 
[You hold me now completely in your hands.

. . . Take Heed! You do not think

A person lives within the page you thumb.

To you this book is paper, cloth, and ink,

Some binding thread and glue, and thus is dumb,

And cannot touch you (though the gaze be great

That seeks you from the printed marks inside) . . . $]^{1}$

It is not surprising to see Whitman borrowings in poems from Germany, but by the time Hitler was in power the enthusiasm for Whitman had cooled. Kolmar's use of Whitman suggests that, unlike some of her immediate predecessors, she read Whitman's work as indicative of a fully democratic society. Whitman's words take on a striking new significance in the hands of a woman and a Jew in Nazi Germany; his work echoes in her "cycles," collections of poems featuring women's voices, children, and a search for a biblical paradise.

The cycle "Images of Woman" starts with the lines I have already quoted. Unlike Whitman's brash and absorptive persona, Kolmar's persona at first meets the reader as an apprehensive bride. Kolmar's bride admits that she is frightened, and perhaps there is some initial irony directed at the gigantic, often fearless, occasionally abstracted "I" of Whitman.

In the third poem, "Woman Undiscovered" ("Die Unerschlossene"), Kolmar's bride has grown in experience. Kolmar assumes for the first time what became her characteristic bold erotic voice:

Auch ich bin ein Weltteil.

Ich habe nie errechte Berge, Buschland undurchdrungen,

Teichbucht, Stromdelta, salzleckende Küstenzungen . . .

Ich bin ein Kontinent, der eines Tages stumm im Meere versinkt.

[I too am a continent.

I have mountains never reached, bush-land unpenetrated,

Bay, stream-delta, salt-licking coast-tongue . . .

I am a continent that one day will sink soundless into the sea. $]^{3}$

These lines bring to mind Whitman's "Starting from Paumanok," which describes an already discovered America. While Kolmar's poetic eroticism is boldly out of step with her country's bourgeois and later totalitarian prescriptions for female comportment, the poignant beginning and ending lines link Kolmar's fate with Europe's. She has little hope that her words will be heard.

In the second "room" of the cycle (Kolmer's terminology reminds us that women are traditionally house-creatures, restricted like the "lady" in Whitman's "Song of Myself" to rooms), the poem called "Girl" ("Mädchen") extends from her room a continent's embrace of the entire world:

Ich will in meinem Bette ruhn und die Erde bedecken.

Über den Ländern Europas und Afrikas liege ich da.

Meinen linken Arm will ich tief hinein nach Asien strecken. 
Und den rechts nach Amerika.

Mein schlängelndes Haar wird im Nordmeer den Alk erschrecken.

[I will rest on my bed and cover the earth.

Over the lands of Europe and Asia I lie,

My left arm reaching deep into Asia,

And the right towards America.

My snaking hair will frighten the auk in Arctic seas. (pp. 66-67)]

This gesture, notes Kolmar's translator Henry A. Smith, is "reminiscent of the expansive ego of Walt Whitman. . . ." (p. 19).

In "The Sinner" ("Die Sünderin") Kolmar takes on the perspective of a woman undergoing the physical-mystical union celebrated in "Song of $\mathrm{My}$ self':

Ich trug die ewig glühende Kohlenkrone, trug sie auf meinem Gewissen.

Einmal ward sie entzündet, verschlungen, gesteigert

In unendliches Wehn, feuerwipfligen Wald.

Ihre Zunge schlug in den Mund, der meinen Schenkel umkrallt, Und nie hat sich stürzender Funke den starken, den reinen Händen des

Jünglings geweigert.

[I wore the eternal crown of glowing coals, wore it upon my conscience.

Once it was ignited, tortuous, climbing in endless waves, a fire-tipped forest.

Its tongue drove down into the mouth that grasped my thigh.

And never did the falling sparks deny the youth's strong, pure hands.

He held it high into the night, a painful torch. . . . $]^{4}$

Kolmar's usual four-beat, $a b a b$ rhyme scheme breaks down in this passionate poem and the lines are much longer. Yet, for a woman, the poet seems to suggest, flights of abstraction tied to sexual union may be well and good, but neither the consequences of a sexual relationship nor those of abstraction can be evaded.

In the later cycle called "Child," "Madness" demonstrates one possible consequence of unchecked abstraction and generality. The poem replaces Whitman's gentle old crone in "Out of the Cradle Endlessly Rocking" with a more threatening female emblem of death: a pale, "Jewish-looking" woman with "tar-like" and "serpentine" black hair who tends a fair-haired child "perhaps already dead." In the end, we realize that she is mad, and rocks an empty cradle in a relentless four-beat meter with $a b a b$ rhyme. The freedom that should have been has no basis. So much for a poet who tries to identify with a nation that holds no hope for her.

After "Child" Kolmar probably wrote her cycle about the French Revolution. Then, as Smith reports, there is a puzzling two-year silence before the appearance of her final cycle, "Worlds." Regarding this last effort, Smith expresses surprise that Kolmar returned to her earlier themes; for Smith, these later poems seem escapist. "Worlds" also surprises him because of its radical 
departure in form from previous work. In "Worlds," Kolmar abandons altogether the conventional four-beat rhyme-scheme she had used most of her life. Previously she had many run-on lines, but here she uses end-stopped lines, anaphora and catalogs, all devices familiar to a reader of Whitman.

Remarkably, Kolmar by this time also abandoned the Whitmanian erotic voice of the "Woman" poems. This suggests that she did not indiscriminately absorb Whitman, nor, I believe, was she being apolitical or escapist. Instead, Kolmar emphasizes the biblical origins of Whitman's democratic form, and looks for the energy that could produce a paradisal earth. ${ }^{5}$ In many of these poems she ponders the failure to realize paradise.

"The Angel in the Forest" ("Der Engel im Walde") is an example of this new style and concern; like Whitman, the speaker takes the hand of the reader, visits vistas (ending in a dusty roadside), and expresses Calamus-like yearnings for friendship.

Gib mir deine Hand, die liebe Hand, und komm mit mir;

Denn wir wollen hinweggehen von den Menschen. . . .

So lass uns fliehn

$\mathrm{Zu}$ den sinnenden Feldern, die freundlich mit Blumen und Gras unsere wandernden Füsse trösten,

An den Strom, der auf seinem Rücken geduldig wuchtende Bürden, schwere, güterstrotzende Schiffe trägt,

$\mathrm{Zu}$ den Tieren des Waldes, die nicht übelreden. . .

Wir werden dürsten und hungern, zusammen erdulden,

Zusammen einst an staubigem Wegesrande sinken und weinen. . . .

[Give me your hand, beloved, and follow me.

And we will go away from men. . . .

So let us flee

Unto the musing fields that will console our wandering feet with friendly flowers and grass,

Unto the river, bearing patiently upon its back the weighty burden of the full, freight-laden ships,

Unto the forest animals that speak no ill. . . .

And we will thirst and hunger and endure together,

And together someday on a dusty roadside we will fall and weep. . . (pp. 203-207; last ellipsis the author's).]

In this poem Kolmar imagines an angelic companion, but a wingless angel, one who will not leave earth, even if it means dying with her. Shortly after writing "Worlds," Kolmar started writing to her sister who had emigrated, explaining in one of her early letters that she could not leave her father, alone and dying, in order to emigrate and save her own life. Although the angel in the poem is male, Kolmar in real life acts the part of the wingless angel. ${ }^{6}$ Did she, like Whitman, contemplate the likelihood that she would die alone, after all she had cared for was gone? 


\section{NOTES}

1 Henry A. Smith, ed. and trans., Dark Soliloquy: The Selected Poems of Gertrud Kolmar (New York: Seabury Press, 1975), 55. Unless otherwise indicated, all subsequent quotations of Kolmar's work are from this volume. For the order and organization of the poems, see Kolmar's complete collection, Das Lyrische Werk (München: Kosel-Verlag, 1960).

2 In a personal letter, November 25, 1988, Walter Grünzweig of the Institut für Amerikanistik in Graz, Austria, suggested that German poets who used Whitman in the 1930s may at times have found the accidental resemblances between Whitman's poetry and Nazi "Blut-und Boden" poetry an embarrassment. Kolmar's better-known cousin, Walter Benjamin, even dismissed Whitman-inspired Franz Werfel as an ultrareactionary. See Michael C. Eben, "Gertrud Kolmar: An Appraisal," German Life and Letters 37 (1984), 197; and Illuminations, ed. Hannah Arendt (New York: Schocken Books, 1969), $227 \mathrm{ff}$. Wilma Brun Merlan discusses Werfel as a pure idealist who rejects the world in "Franz Werfel, Poet," Franz Werful 1890-1945, ed. Lore B. Foltin (Pittsburgh: University of Pittsburgh Press, 1961), 26-38. The poetry she quotes suggests a Whitman following Emerson's advice and leaving out the body. At least one prose writer, Thomas Mann, seems to have successfully used Whitman against oppressive government; see Robert K. Martin, "Walt Whitman and Thomas Mann," Walt Whitman Quarterly Review 4 (Summer 1986), 1-6.

3 I have modified Smith's translation to a more literal rendition which emphasizes the eroticism in Kolmar's word-play. For the original, see pp. 59-60.

4 Smith captures erotic undertones here, but I have modified his translation to demonstrate how Kolmar was employing lists in the manner of Whitman (see pp. 76-79).

5 In showing that most of Whitman's characteristic techniques of form are traceable to the King James Bible, Gay Wilson Allen, The New Walt Whitman Handbook (New York: New York University Press, 1986), remarks: "The structure of Hebraic poetry, even in English translation, is almost lacking in subordination" (p. 215). The form is suitable for a poetry that undermines tyranny.

6 Gertrud Kolmar, Briefe an die Schwester Hilde (München: Kosel-Verlag, 1970), 9-15. Especially see the letter dated November 24, 1938.

\section{ON THE BACK COVER: WHITMAN AND WORCESTER}

Devoted as Walt Whitman was to the study of "words," it is not surprising that there has come to light an example of his signature on the title page of an 1849 dictionary. Descendants of Thomas B. Harned, one of Whitman's three literary executors, had saved this page for the sake of the signature, but the rest of the book has been lost. Professor Joel Myerson of the University of South Carolina recently purchased this title page and other Whitman memorabilia, including several volumes of Whitman's works inscribed to Harned by the poet; the facsimile on the back cover appears courtesy of Professor Myerson.

The significance of Whitman's autograph on this particular title page is the implication that he owned and used this reprint of the 1846 edition of 